\title{
STRATEGI DINAS KEBUDAYAAN DAN PARIWISATA DALAM PROMOSI TEMPAT WISATA DI KOTA PALANGKA RAYA
}

\author{
The strategy of culture and tourism in the promotion of tourist attractions \\ in the city of Palangka Raya
}

\section{Muhamad Yusuf \\ Andry Febri Pratama}

Universitas Muhammadiyah Palangkaraya, Palangka Raya, Central Kalimantan, Indonesia

email:

yusuf.quratayun@gmail.com

\author{
Kata Kunci: \\ Strategi \\ Promosi \\ Tempat Wisata
}

\section{Keywords:}

Strategy

Promotion

Sightseeing spots

\begin{abstract}
Abstrak
Penelitian ini bertujuan untuk mengetahui dan menganalisis strategi Dinas Kebudayaan dan Pariwisata dalam mempromosikan tempat/produk wisata kepada masyarakat maupun wisatawan. Selain itu juga untuk mengetahui apa saja kendala dalam mempromosikan tempat wisata di Kota Palangka Raya. Penelitian ini menggunakan penelitian kualitatif, yang menjadi instrumennya adalah peneliti sendiri sehingga untuk dapat menjadi instrumen maka peneliti harus memiliki bekal teori dan wawasan yang luas, sehingga mampu bertanya, menganalisis, memotret, dan mengkontruksi obyek yang di teliti menjadi lebih jelas dan bermakna. Dalam penelitian kualitatif, pengumpulan data tidak di pandu teori, tetapi di pandu oleh fakta-fakta yang di temukan pada saat penelitian di lapangan.

Berdasarkan hasil analisa data dapat di jelaskan bahwa strategi yang harus di lakukan dalam Pemasaran promosi wisata yaitu dengan cara membuat acara seperti menunjukan kecirikhasan daerah, pameran budaya, parade kapal susur sungai. $\mathrm{Hal}$ - hal seperti itulah yang akan menarik wisatawan tinggal bagaimana pengemasan objek wisata dan promosinya. Kegiatan seperti itu bisa di lakukan di tengah pusat kota agar masyarakat maupun wisatawan mudah menjangkau lokasi, Selain itu juga harus mengemas produk yang mempunyai nilai jual budaya, Harga sesuai Fasilitas, serta yang paling penting Mempersiapkan Tempat unggulan wisata yang benar-benar matang dari segi insfrastruktur, sarana dan prasarana. Bagi pemerintah dan penggerak jasa pariwisata dari segi Strategi dalam promosi yaitu daya dukungnya perlu di tingkatkan lagi agar Kota Cantik kita ini di kenal di daerah lain, karena di sayangkan apabila kota ini tenggelam dalam dunia pariwisatanya padahal menyimpan segudang sejarah, Keasrianalam, dan Ketenangan Kotanya.
\end{abstract}

\section{Accepted}

January 2018

\section{Published}

April 2018

\section{PENDAHULUAN}

Potensi pariwisata di Kalimantan Tengah sangat menjanjikan. Sebab kebudayaan Kalantan Tengah

\begin{abstract}
This research aims to know and analyze the strategy of the Culture and Tourism office in promoting the place/tourism products to the public and tourists. Also, to find out what are the obstacles to promoting tourist attractions in the city of Palangka Raya. This research uses qualitative research, which is the instrument is the researcher himself to be able to become instruments then the researcher must have $a$ wide provision of theory and insight, to be able to ask, analyze, photograph, and To contract objects that are meticulously clearer and meaningful. In qualitative research, data collection is not in the theory of the Guide but guided by the facts found at the time of research in the field.

Based on the results of data analysis can be explained that the strategy that should be done in the marketing of tourism promotion is to make the event such as showing the regional peculiarities, cultural exhibitions, river ship parade. Things like that will attract tourists to stay how packing the attraction and its promotion. Such activities can be done in the middle of the city center so that people and tourists easily reach the location, in addition it should also package products that have the value of cultural selling, price according to facilities, and most importantly prepare a place The Tour's flagship is truly mature in terms of infrastructure, facilities, and infrastructure. For government and Tourism service drivers in terms of strategy in the promotion is the supporting power needs to be improved again so that our beautiful city is known in other regions, because it is in the world when the city is immersed in its tourism, but $A$ myriad of historical, Acirianalam, and the tranquility of the city.
\end{abstract}

memiliki keunikan dan kekhasan tersendiri dari provinsi lain. Selain itu Kalteng juga mempunyai banyak sekali obyek wisata seperti wisata alam, wisata sejarah, wisata budaya, wisata minat khusus, wisata kuliner, 
wisata olah raga, dan wisata belanja. Palangka Raya merupakan lbu Kota Kalimantan Tengah letaknya yang Strategis dan memiliki tatanan Kota yang rapi bisa di perhatikan Dari atas Palangkaraya begitu bagus dan terstruktur semua jalan lurus menuju kearah satu bundaran yang menghubungkan jalan satu dengan yang lainnya. Serta Tempat Wisata yang masih asri dan alami dan memiliki konservasi orang hutan hewan yang hampir Punah. Hal menarik lainnya adalah kondisi alam kota Palangka Raya berupa dataran yang dibelah oleh Sungai Kahayan dan dikelilingi rawa gambut. Aliran air permukaan yang mengalir di wilayah Kota Palangka Raya adalah Sungai Kahayan, Sungai Rungan dan Sungai Sabangau. Sungai-sungai dengan anak-anak sungainya tersebut adalah prasarana transportasi alam yang sangat penting, karena sungai-sungai tersebut menghubungkan wilayah Kota Palangka Raya dengan wilayah sekitarnya dan menghubungkan desa-desa di wilayah utara Kota Palangka Raya dengan pusat kotanya.

Namun Strategi promosi Pengelola tempat Wisata di Kota Palangka Raya masih belum maksimal dan bisa di bilang lemah, belum menyeluruh dan belum masuk ke tengah masyarakat. Mengingat pariwisata merupakan sektor pendapatan daerah. selain itu juga Pariwisata menjadi ciri khas daerah yang mudah di kenal masyarakat luas khususnya Wisatawan yang berkunjung kedaerah tersebut. Akan tetapi, permasalahannya di Kota Palangka Raya ini sangat sulit menemukan ciri khasannya seperti ikon kota yang mudah di ingat orang lain, tidak seperti kota kota lain yang sudah menemukan ikon daerah dan menjadikan objek wisata secara otomoatis membuat pemasukan daerah yang tak terduga dari kedatangan wisatawan tersebut. Walaupun jaman sudah berkembang dengan pesat dengan adanya teknologi namun beberapa wisatawan tanpa pemandu wisata juga memerlukan informasi dari masyarakat yang ada di sekitar untuk mendapatkan informasi yang lebih akurat tentang objek dayatarik wisata di Kota palangka Raya.
Belum maksimalnya promosi wisata di kota Palangka Raya sangatlah di sayangkan maka dari itu sebagai peneliti sangat tertarik untuk mengetahui lebih dalam agar menyelamatkan Pariwisata aset daerah yang potensial serta jarang di miliki daerah lainnya di indonesia, menginat Wisatwan adalah sumber pendapatan praktis untuk pemasukan daerah.

Menurut Kotler dan Amstrong (Suryadana, 20I5:2I) Strategi pemasaran terdiri dari prinsip-prinsip dasar yang mendasari manajemen untuk mencapai tujuan bisnis dan pemasarannya dalam sebuah pasar sasaran, strategi pemasaran mengandung keputusan dasar tentang pemasaran, bauran pemasaran, bauran pemasaran dan alokasi pemasaran.

Elemen bauran pemasaran untuk destinasi pariwisata yaitu bisa di lihat dari produk Menurut Edgell dan Hill dalamProduk pariwisata berbeda dengan produk pada umumnya karena mencakup berbagai bidang di antaranya: akomodasi, transportasi, makanan, rekreasi, dan atraksi. Selain itu produk pariwisata juga mencakup hal-hal yang tidak berwujud seperti sejarah, budaya, dan keindahan alam. Dalam konteks pariwisata ada harga atau bisa di sebut dengan sejumlah uang yang wisatawan keluarkan untuk produk atau jasa yang di dapatkan saat berwisata. Pengalaman berwisata yang sebanding dengan harga yang di keluarkan adalah hal yang paling di cari oleh wisatawan. Penetapan harga harus berdasarkan pemaksimalan keuntungan, pesaing dan pangsa pasar.

\section{METODOLOGI}

Jenis penelitian ini adalah penelitian kualitatif, yang menjadi instrumennya adalah peneliti itu sendiri sehingga untuk dapat menjadi instrumen maka peneliti harus memiliki bekal teori dan wawasan yang luas, sehingga mampu bertanya, menganalisis, memotret, dan mengkontruksi obyek yang di teliti menjadi lebih jelas dan bermakna. Dalam penelitian kualitatif, 
pengumpulan data tidak di pandu teori, tetapi di pandu oleh fakta-fakta yang di temukan pada saat penelitian di lapangan.

\section{HASIL DAN PEMBAHASAN}

Strategi dalam promosi tempat wisata di palangka Raya yang cocok di saat ini dengan berkembangnya zaman teknologi adalah hal yang tidak bisa di hindarkan.Jaman yang serba instan harus dibarengi dengan sesuatu yang cepat. Dengan internet masyarakat sangatlah mudah untuk menjangkau keseluruhan informasi dari penjuru dunia.

Sumber daya manusia juga berpengaruh dalam strategi promosi maka dari itu Dinas maupun jasa penyedia perjalanan wisata harus bisa menyeimbangkan promosi melalui digital seperti memiliki web yang selalu aktif dan terus memperbaharui informasi baru agar wisatawan mudah mengakses dan mendapatkan informasi yang valid dan terbaru. Alangkah baiknya lagi bisa berinteraksi walaupun jarak dan waktu yang berbeda atau pun jauh wisatwan bisa berkomunikasi dengan baik dengan menggunakan media pesan atau pun panggilan video. Ini hal yang kecil tapi mampu membuat kesan bahwa tempat wisata sangat siap untuk di kunjugi dan bahkan wisatawan tidak perlu kebingungan lagi ketika datang, tidak perlu lagi mencari informasi atau mengatur jadwal wisata mereka.

Dalam bidang strategi promosi pariwisata di daerah palangka Raya tak lepas juga dari peran masyarkatnya sendiri dalam mempromosikan Objek Daya Tarik Wisata. Banyaknya tempat wisata yang belum siap membuat Bagian Promosi Dinas Kebudayaan dan Pariwisata Kota Palangka Raya sedikit kesulitan untuk mempromosikan di lihat dari akses jalan menuju tempat wisata dan sarana prasaranya yang ada di objek wisata, bahkan anggaran yang di miliki untuk promosi masih minim. bagaimana mereka bisa mempromosikan apabila daya dukung tidak memadai seperti jalan menuju tempat wisata, dari segi keamanan, fasilitas penunjang seperti trasnpotasi, toilet umum, dan terkadang biaya akses menuju objek wisata mahal.

Ini sangat di sayangkan, seharusnya ibu Kota Provinsi haruslah di prioritaskan dalam Pembangunan Objek Wisata mengingat Tempat wisata dapat mendatangkan wisatawan yang bisa membuat pemasukan daerahyang terbilang tidak sedikit. Serta bisa menciptakan lapangan pekerjaan baru bagi masyarakat sekitar objek wisata dan hal ini tidak akan ada pihak

yang di rugikan. Hal positif lainnya yaitu Palangka Raya mudah di kenal masyarakat, kebanyakan masyarakat di luar seperti pulau jawa sangat awam mendengar Kota Palangkaraya di karenakan tidak ada keunggulan wisatanya atau dari segi maskot Kotanya yang masih belum menemukan jati diri sebagai kota Palangka Raya.

Melihat potensi Palangka Raya sangatlah strategis berada di tengah-tengah khatulistiwa, Perdesaan dengan rumah adat yang masih terjaga, serta memiliki wajah hutan yang masih asri sebagai jantung hutan dunia belum terkontaminasi polusi karena di palangka Raya tidak ada pabrik, hal ini yang tidak di miliki daerah lain yang mulai terkontaminasi polusi-polusi pabrik. Selain Daya dukung dari Pemerintah yang kurang dari segi sarana prasarana, Peran masyarakat juga sangat penting dalam promosi tempat wisata di Kota Palangka Raya, Terkadang mereka kebingungan hal apa saja yang menarik di lbu Kota Provinsi tercinta ini. Padahal di Palangka Raya ada yang bagus untuk edukasi generasi penerus sebelum hewan yang terancam punah ini benar-benar punah, seperti ke Pulau Kaja tempat pelepasan liar Orang Hutan, walaupun tidak setiap hari di kunjungi, karena untuk menjaga intensitas orang hutan tetap tenang.

Bahkan wisata di dalam kota cukup menarik dengan mitos dan kepercayaan masyarakat pada jaman dahulu, tidak ketinggalan wisata kuliner tidak kalah enak dengan daerah lain, serta Filosfi rumah betang yang melekat bagi Suku Dayak. Promosi tempat wisata sangatlah berpengaruh demi mendongkrak wisatawan 
asing maupun lokal, wisatawan akan berbondongbondong dating apabila promosi di lakukan dengan strategi yang jitu. Seperti memanfaatkan teknologi digital tapi dengan catatan di dukunginsfrastruktur yang memadai demi kenyamanan wisatawan agar membawa kesan tersendiri ketika pulang kedaerahnya.

Adapun harapan investor Lokal untuk mengembangkan tempat wisata di Palangka Raya. Pemerintah akan senang terutama Dinas Kebudayaan dan Pariwisata, ini menunjukan kekayaan alam di Palangaka Raya di perhitungkan dalam berbisnis Wisata. Karena yang di ketahui selama ini Investor di Palangka Raya hanya Berbisnis Tambang Batu Bara dan Pasir sirkon. Cukup menariknya kota ini juga di lihat dari kehidupan Kota yang di bilang tenang, Tidak ada macet hanya hari tertentu saja misalkan lebaran dan hari besar lainnya, jalan raya yang cukup lebar dan mulai di hiasi dengan Taman-Taman Kota untuk Rekreasi, Seta Kebersihan Kota yang mulai terjaga. Cocok untuk berakhir pekan bagi yang ingin mendapatkan ketenangan dalam nuansa Kota.

Kegiatan lain yang harus di lakukan yaitu membuat acara seperti menunjukan ke ciri khasan daerah, pameran budaya, parade kapal susur sungai. Hal - hal seperti itu lah yang akan menarik wisatawan tinggal bagaimana pengemasan objek wisata dan promosinya. Kegiatan seperti itu bisa di lakukan di tengah pusat kota agar masyarakat maupun wisatawan mudah menjangkau lokasi. Yang harus di terapkan Para penggerak jasa Perjalanan maupun Dinas Kebudayaan dan Pariwisata Kota Palangka Raya yaitu membuat produk wisata unggulan, Harga yang mampu bersaing dari segi pelayanandan fasilitas yang sepadan. Di sertai promosi yang mampu benar-benar masuk ke tengah masyarakat dari usia rejama sampai lansia.

Pemerintah maupun Dinas terkait juga harus mempersiapkan Tempat yang akan menjadi andalan wisata, Persiapan haruslah matang dari segala elemen seperti Transportasi, Akses jalan yang mudah,
Akomodasi yang memadai. Penetapan segmen pasar juga di perlukan di dalam Pariwisata diPalangka Raya untuk proses mengevaluasi setiap daya tarik segmen kemudian memilih satu atau lebih karakteristik untuk di layani. Penargetan pasar juga persoalan bagaimana memilih, menyeleksi, dan menjangkau pasar. Menetapkan target pasar merupakan tahap selanjutnya dari analisis segmentasi. Produk dari menetapkan target pasar ini yaitu satu atau beberapa segmen pasar yang akan menjadi fokus kegiatan-kegiatan pemasaran. Proses ini mencerminkan kenyataan bahwa Dinas dan penggiat jasa wisata harus mengidentifikasi pelanggan yang dapat di akses dan dilayani secara efektif dan efisien.

Palangkara Raya juga harus menyiapkan Komponen Pengembangan Pariwisata yang dapat di kelompokkan :

I. Atraksi dan kegiatan-kegiatan wisata

Kegiatan-kegiatan wisata yang di maksud dapat berupa semua hal yang berhubungan dengan lingkungan alami, kebudayaan, keunikan suatu daerah dan kegiatan-kegiatan lain yang lain berhubungan dengan kegiatan wisata yang menarik wisatawan untuk mengunjungi Palangka Raya Misalkan mengadakan agenda Parade Kapal adat dayak di susur sungai Kahayan setiap bulan dengan tema berbeda.

2. Akomodasi

Berbagai macam hotel dan berbagai jenis fasilitas lain yang berhubungan dengan pelayanan untuk para wisatawan yang berniat untuk bermalam selama perjalanan wisata yang mereka lakukan. Menawarkan harga terbaik dan sesuai dengan kualitas.

3. Fasilitas dan Pelayanan Wisata

Fasilitas dan pelayanan wisata yang di maksud adalah semua fasilitas yang di butuhkan dalam perencanaan kawasan wisata. Fasilitas termasuk pelayanan penyambutan di bandara ketika datang. Jenis tempat makan lainnya, toko- 
toko untuk menjual hasil kerajinan tangan, cindramata, bank untuk penukaran mata uang asing, kantor informasi wisata, fasilitas keamanan dan kesehatan, serta fasilitas untuk keluar dan masuk seperti kantor imigrasi.

4. Fasilitas dan Pelayanan Transportasi

Meliputi transportasi akses dari dan menuju kawasan wisata, transportasi internal yang menghubungan atraksi utama kawasan wisata dan kawasan pembangunan, termasuk semua jenis fasilitas dan pelayanan yang berhubungan dengan transportasi darat, air, dan udara.

5. Insfastuktur lain

Insfrastruktur yang di maksud adalah penyedia air bersih di tempat wisata dan telekomunikasi untuk keadaan darurat.

6. Elemen kelembagaan

Kelembagaan yang di perlukan untuk membangaun dan mengelola kegiatan wisata, termasuk perencanaan tenaga kerja dan program pendidikan, pelatihan menyusun strategi marketing dan program promosi menstrukturisasi organisasi wisata sektor umum dan swasta. Menentukan kebijakan penanaman modal bagi sektor publik dan swasta, mengendalikan program ekonomi, lingkungan, dan sosial kebudayaan.

Strategi-strategi hal kecil juga sangat berpengaruh dalam mempromosikan tempat wisata di palangka Raya yaitu dengan mempromosikan wisata yang menarik seperti acara kedaerahan dan kebudayaan ataupun wisata alam, buatan manusia di sosial media masingmasing masyarakat. Hal itu akan cepat sampai ke masyarakat luas karena kecanggihan dan kekuatan sosial media sangat luar biasa di era ini. Selain dari strategi promosi masyarakat Dinas terkait juga harus melek teknologi harus memiliki sumber daya manusia yang siap mental dan visioner dalam berpikir untuk menyeimbankan situasi yang ada. Fasilitas lainnya yaitu posko informasi wisatawan ketika di kedatangan bandara.Ini sangat penting dan berpengaruh besar karena wisatawan ada dua tipe berkunjung ke suatu daerah sendiri dan tanpapemandu wisata dan wisatawan yang sudah menggunakan jasa perjalanan wisata.

Perlakuan khusus untuk wisatawan yang datang tanpa pemandu wisata akan memberikan kesan bahwa kota ini sangat baik dalam menyambut kedatangan wisatawan agar tau arah tujuan dan memperkenalkan kota cantik ini. Selain itu hal terpenting adalah membuat fasilitas-fasilitas yang di perlukan wisatawan untuk kemudahan di tempat wisata seperti posko keamanan, posko kesehatan, jaringan telekomunikasi ketika keadaan darurat, air bersih, dan wC umum. Masyarakat luar harus mengetahui Kota Palangka Raya karena Kota ini merupakan Kota yang bisa di kenal dengan paru-paru dunia, agar mereka menjaga dan melindungi hutan dan hewan endemik yang terancam punah, berbekal edukasi wisata akan membuat masyarakat terbuka terhadap Palangka Raya ini, dan akan membangun wisata lebih baik dari sebelumnya, serta sumber daya manusianya di latih menjaga dan bangga akan karunia sang pencipta. Tantangan pasti selalu ada untuk membangun tetapi apabila tidak di iringi dengan langkah kecil kapan harapan akan terwujud. Maka dari itu pemerintah, masyarakat, dan penggerak jasa wisata serta elemen lainnya harus bersatu dan meluruskan visi, misi bersama untuk lebih mengenalkan objek daya tarik wisata di Kalimantan tengah khusunya Provinsi di Kota Palangka Raya.

\section{KESIMPULAN}

Dari segi Strategi dalam promosi serta daya dukungnya perlu di tingkatkan lagi agar Kota Cantik kita ini di kenal di daerah lain, karena di sayangkan apabila kota ini tenggelam dalam dunia pariwisatanya padahal menyimpan segudang sejarah, Keasrian alam, dan Ketenangan Kotanya. Selanjunya agar lebih di perhatikan akan potensi-potensi daerah yang mampu 
mengangkat nama palangkaraya misalkan mengenalkan Kaja terlebih dahulu karena di situ Palangka Raya punya nilai lebih karena di lbu Kota Provinsi sangat langka ada hewan endemik yang akan mulai Punah. Disitu bisa memperkenalkan kepada anak cucu agar mengetahui kehidupan orang hutan yang sesungguhnya dan bisa menjadi edukasi sejak dini.

Meningkatkan sarana penunjang seperti transportasi umum darat maupun air untuk kemudahan berwisata agar ekonomis bagi wisatawan pendatang, Akes jalan yang mudah, dan Fasilitas-Fasilitas Umum yang memadai. dan yang pasti agar meningkatkan anggaran per tahun untuk promosi wisata dan pengelolaannya. Tidak usah takut akan rugi apabila di anggarkan dengan baik maka ini bukan hal yang tidak mungkin Provinsi mampu menyerap pemasukan melalui Pariwisata. Bagian promosi Dinas Kebudayaan Dan Pariwisata Kota Palangka Raya juga harus terus melakukan promosi di pusat kota seperti memberi peta informasi wisata yang bisa di tuju wisatawan, dan memberikan opsi-opsi tempat yang harus di kunjungi dari segi budaya, alam maupun kuliner.

\section{REFERENSI}

Cangara, Hafied. 2013. Perencanaan \& Strategi Komunikasi. Jakarta: PT.Raja Grafinda Persada.

Hunger, J. David dan Thomas L W. 2003. Manajemen Strategis. Andi. Yogyakarta.

Kuncoro, Mudrajad. 2006. Strategi Bagaimana Meraih Keunggulan Kompetitif. Jakarta : Erlangga.

Kusudianto, Hadiono. $1996 . \quad$ Perencanaan Pengembangan Destinasty Pariwisata. Jakarta : UI Press.

Nawawi, Hadari. 2005. Manajemen Strategik Untuk Organisasi Public dan Organisasi non di Bidang Pemerintahan. Yogyakarta : University Press.

Pasolong, Harbani. 2012. Metode Penelitian Administrasi Publik. Bandung : Alfabeta.

Pitana, I Gede Dkk. 2004. Sosiologi Pariwisata. Yogyakarta.
Siagian, Sondang P. Manajemen Stratejik. 2012. Jakarta : Bumi Aksara.

Sugiyono. 2007. Metodologi Penelitian Kualitatif. Bandung : PT Remaja Rosdakarya.

Sunaryo, Bambang. 2013. Kebijakan Pembangunan Destinasi Pariwisata Konsep dan Aplikasinya Di Indonesia. Yogyakarta: Gava media. 